\title{
Ultrasonographic detection, definition and quantification of soft tissue oedema in psoriatic dactylitis
}

\author{
Ilaria Tinazzi ${ }^{1}$, Luca Idolazzi ${ }^{2}$, Alen Zabotti ${ }^{3}$, Luisa Arancio ${ }^{4}$ Alberto Batticiotto ${ }^{5}$, Cristian \\ Caimmi $^{2}$, Orazio De Lucia ${ }^{6}$, Angelo Fassio ${ }^{2}$, Nicolò Girolimetto ${ }^{7}$, Pierluigi Macchioni ${ }^{7}$, \\ Antonella Murgo ${ }^{6}$, Garifallia Sakellariou ${ }^{8}$, Annamaria Iagnocco 9
}

${ }^{1}$ IRCCS Sacro Cuore Don Calabria Hospital, Negrar, Verona, ${ }^{2}$ Rheumatology Unit, University of Verona, Ospedale Civile Maggiore, Verona, ${ }^{3}$ Department of Medical and Biological Science, Rheumatology Clinic, Azienda Sanitaria Universitaria Integrata, Udine, ${ }^{4}$ Unit of Dermatology, Fondazione IRCCS Cà Granda Ospedale Maggiore Policlinico, Milan, ${ }^{5}$ Department of Internal Medicine, Rheumatology Unit, ASST-Settelaghi "Ospedale di Circolo-Fondazione Macchi" Varese, 'Unit of Clinical Rheumatology, Department of Rheumatology and Clinical Sciences, ASST Centro Traumatologico Ortopedico G. Pini - CTO, Milan, ${ }^{7}$ Rheumatology Unit, Department of Internal Medicine, Azienda Ospedaliera ASMN, Istituto di Ricovero e Cura a Carattere Scientifico, Reggio Emilia, ${ }^{8} \mathrm{Chair}$ and Division of Rheumatology, University of Pavia, IRCCS Policlinico San Matteo Foundation, Pavia, ${ }^{9}$ Academic Rheumatology Centre, Università degli Studi di Torino, Turin, Italy

\begin{abstract}
Aim: To define and score finger soft tissue oedema in psoriatic dactylitis by ultrasound. Material and methods: A systematic literature review (SLR) on ultrasound-detected finger soft tissue oedema was performed. Subsequently, based on the SLR, a Delphi survey was developed and circulated among a group of 13 expert sonographers, in order to obtain agreement on detection, definition and scoring of finger oedema by B-mode and power Doppler ultrasound. Agreement was considered achieved when each statement was approved by $\geq 75 \%$ of participants. Results: At the first Delphi round, $91 \%$ agreement was obtained for the scanning technique to adopt, including the most appropriate area to evaluate. At the second round, $76 \%$ agreement was achieved on the definition of soft tissue finger oedema. At the third round, $76 \%$ agreement was obtained for B-mode and power Doppler scores. The volar aspect of the finger and comparisons with the contralateral side were agreed to be the most appropriate in terms of scanning technique. Agreed ultrasound definition of finger soft tissue oedema was "abnormal hypoechoic/anechoic areas, diffused or localized within the subcutaneous tissue between the epidermidis and the tendon-related anatomic structures (i.e. flexor tendon sheath, peritenonium, tendon pulleys), with local thickening, with or without local abnormal Doppler signal, visualised in two perpendicular planes and not evident on the contralateral side". Semiquantitative (0-3) scores for both B-mode and power Doppler were agreed to be the most appropriate to be used. Conclusion: Our work produced, for the first time, technical indications, definition and scoring for the ultrasound assessment of soft tissue oedema in psoriatic dactylitis.
\end{abstract}

Keywords: soft tissue oedema; dactylitis; ultrasonography; Delphi

Received 10.09.2019 Accepted 23.10.2019

Med Ultrason

2019, Vol. 21, No 4, 414-421

Corresponding author: Prof. Annamaria Iagnocco

Academic Rheumatology Centre,

Dipartimento Scienze Cliniche e Biologiche,

Università degli Studi di Torino,

Regione Gonzole Orbassano - Turin, Italy

E-mail: annamaria.iagnocco1@gmail.com

\section{Introduction}

Soft tissue oedema (STOe) of the finger is present in different diseases but it is a recurrent finding in Psoriatic Arthritis (PsA), particularly in dactylitis in which it is a pivotal lesion. Dactylitis is the hallmark of PsA and of the whole spondyloarthritis ( $\mathrm{SpA}$ ) group of diseases. Furthermore, this clinical feature is part of Classifica- 
tion Criteria for PsA (CASPAR). Dactylitis is defined as a fusiform swelling of the digit that involves three main anatomical structures: joints, synovial sheaths of flexor tendons and soft tissue surrounding tendons and ligaments [1]. Besides the diagnostic role, dactylitis seems to be a marker of disease severity in PsA [2]. As musculoskeletal ultrasound (US) has become a relevant tool for diagnosis and for patient follow up in rheumatic and musculoskeletal diseases, there is an increasing need to identify specific US lesions and to score them [3].

While current scoring methods for US-detected digit synovitis and tenosynovitis are widely approved [4,5], there is a lack of US studies focusing on a widely accepted definition of STOe. Fournier et al [6] were the first to describe the peri-tendinous finger oedema as a diffused hypo/isoechoic thickening of the peritendinous soft tissues around flexor tendon with an increased power Doppler (PD) signal. This definition was recently applied in other US studies, showing that STOe of the digit in PsA patients, even without clinical dactylitis, could be useful for differential diagnosis between PsA and RA [7-9]. A new definition of an elementary lesion detected by US can be developed by a group of experts through a Delphi process that provides the creation of an agreed and clear definition, which includes also all the aspects that are susceptible to change after therapy. The aim of this study was to produce a consensus-based definition and develop a scoring system for US-detected finger STOe in psoriatic dactylitis.

\section{Materials and methods}

\section{Design of the study}

A systematic literature review (SLR) on US-detected finger oedema dactylitis was performed. Based on its results, a Delphi survey on the scanning technique, definition and grade of US-detected pathology was circulated among a group of experts in the field of US and dactylitis.

\section{Systematic Literature Review}

The recently published SLR [10] on the use of musculoskeletal US for PsA and psoriasis ( $\mathrm{PsO}$ ) patients, updated to September 2015, was used as the starting point for performing an additional SLR on US in PsA, with a focus on STOe. The aim of the previous SLR was that of providing a wide overview on all the possible applications of musculoskeletal US in PsA, through a sensitive, non-specific search strategy (Supplementary Table S1). The SLR on this general question was updated (September 2015 - January 2018) by the same authors (AZ, GS, AI) via PubMed and Embase, while the abstract from the ACR and EULAR congresses of the previous 2 years

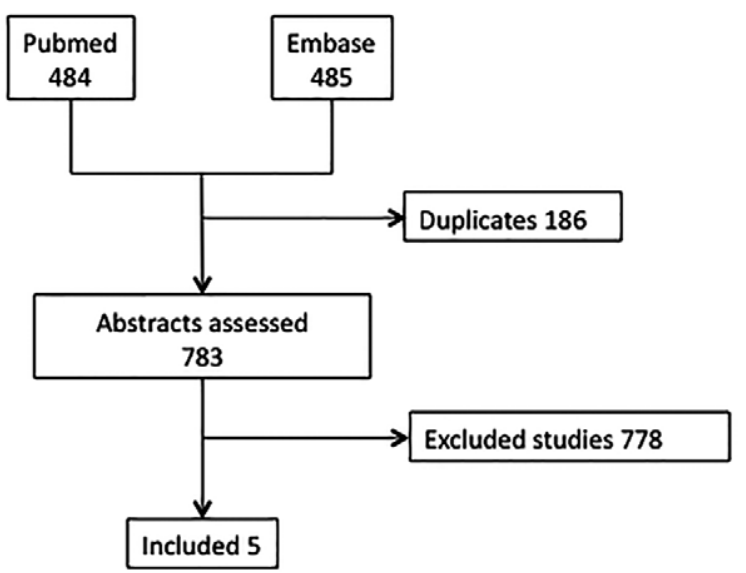

Fig 1. Flow-chart showing the overall selection process of the SLR for the research questions on subcutaneous oedema in PsA.

were hand searched. The references of the included studies were screened to look for additional eligible studies. A total of 14 additional studies on the use of US in PsA were selected ( 3 identified by hand search and 2 among ACR/EULAR abstracts). The results of the original SLR and those of the update were afterwards reviewed in light of the new research questions, with a focus on STOe (How was STOe in PsA defined? What is the performance of US in detecting STOe in PsA? What is the performance of US-detected STOe in diagnosing PsA?), driving to the final inclusion of 5 studies $[8,9,11,12]$ (fig 1), whose results were summarized into a summary of a findings table (Table I). When data on the performance of primary studies to diagnose STOe or PsA were available, those were extracted into $2 \times 2$ tables and measures of diagnostic accuracy were calculated. Four studies reported heterogeneous definitions of STOe, while 4 allowed the extraction of data to assess the diagnostic performance of this lesion in diagnosing PsA vs RA, showing a high specificity. The results of the SLR were presented to all participants to the study before the Delphi exercise, and statements covering definitions and scoring systems for the Delphi exercise were then developed.

\section{Delphi survey}

Based on the results of the updated SLR, a Delphi survey on the scanning technique, definition and characteristics of US STOe lesions in patients with dactylitis was circulated among a group of experts in the field of US and PsA dactylitis. The experts were selected from Italian specialists and they worked in 8 different collaborating Italian Rheumatology Departments with expertise in US and PsA management (12 rheumatologists and one dermatologist). Different sets of abnormalities and scoring systems were included in the proposed statements for STOe and its grade (i.e. echogenicity, localization and 
severity of soft tissue oedema during dynamic scanning). At each round, participants rated their level of agreement for each statement according to a Likert scale $(1=$ strongly disagree to $5=$ strongly agree) and gave their comments. Agreement was considered achieved when each statement was approved (points 4 and 5 on the Likert scale) by $\geq 75 \%$ of participants. Based on the results and comments obtained, the statements that were not agreed were modified and proposed to the participants again at the subsequent rounds. Statements that did not reach the $\geq 75 \%$ cut-off point were modified according to the comments and proposed again for voting. The Delphi was considered completed when agreement was achieved for all categories of the survey and the panel proposed no further modifications.

\section{Results}

All of the invited participants responded to the first, second and third Delphi questionnaire (100\% response

Table I. Summary of findings of the SLR

\begin{tabular}{|c|c|c|c|c|c|}
\hline Study & Population & Intervention & $\begin{array}{l}\text { Comparator } \\
\text { standard }\end{array}$ & Definition and outcome & Results \\
\hline $\begin{array}{l}\text { Fournié } \\
2006 \\
{[6]}\end{array}$ & $\begin{array}{l}20 \text { PsA (25 fingers) } \\
21 \text { RA (25 fingers) }\end{array}$ & $\begin{array}{l}\text { US of } \\
\text { symptomatic } \\
\text { fingers } \\
13.5 \mathrm{MHz} \\
\text { transducer }\end{array}$ & n.a. & $\begin{array}{l}\text { Oedema defined as "diffuse } \\
\text { thickening of the soft tissues"; } \\
\text { "either diffuse or confined to the } \\
\text { finger pad, including the four } \\
\text { fingers with pseudotenosynovitis } \\
\text { and the three fingers with finger } \\
\text { pad inflammation". }\end{array}$ & $\begin{array}{l}\text { Soft tissue thickening re- } \\
\text { ported in } 8 \text { fingers from PsA } \\
\text { patients and in no finger from } \\
\text { RA patients. }\end{array}$ \\
\hline $\begin{array}{l}\text { Lin } \\
2016 \\
{[12]}\end{array}$ & $\begin{array}{l}44 \text { PsA (133 fin- } \\
\text { gers) } \\
39 \text { RA (132 fingers) } \\
20 \text { HC }\end{array}$ & $\begin{array}{l}\text { US of } \\
\text { hand fingers } \\
18 \mathrm{MHz} \\
\text { transducer }\end{array}$ & $\begin{array}{l}\text { Clinical } \\
\text { diagnosis }\end{array}$ & $\begin{array}{l}\text { No definition. } \\
\text { The outcome was the diagno- } \\
\text { sis of PsA, fingers are used as } \\
\text { statistical units. }\end{array}$ & $\begin{array}{l}\text { Performance of soft tissue } \\
\text { oedema to diagnose PsA vs } \\
\text { RA: } \\
\text { Se }(95 \% \text { CI }) 0.35(0.27,0.44) \\
\text { Sp }(95 \% \text { CI } 1(0.97,1) \\
\text { LR- } 0.64(0.56,0.73) \\
\text { PPV } 1 \\
\text { NPV } 0.61(0.57,0.63)\end{array}$ \\
\hline $\begin{array}{l}\text { Zabotti } \\
2016 \\
{[8]}\end{array}$ & $\begin{array}{l}26 \text { early PsA } \\
34 \text { early RA } \\
\text { With prevalent } \\
\text { involvement of the } \\
\text { hand }\end{array}$ & $\begin{array}{l}\text { US of } \\
\text { the two most } \\
\text { clinically } \\
\text { involved joints; } \\
\text { dactylitis } \\
\text { excluded. } \\
16-18 \mathrm{MHz} \\
\text { transducer }\end{array}$ & $\begin{array}{l}\text { Clinical } \\
\text { diagnosis }\end{array}$ & $\begin{array}{l}\text { "Soft tissue oedema was defined } \\
\text { as a diffuse enlargement of soft } \\
\text { tissue around the flexor tendon, } \\
\text { with an increased power doppler } \\
\text { signal, from finger pad to MCP } \\
\text { joint and it was evaluated by } \\
\text { volar scan" }\end{array}$ & $\begin{array}{l}\text { Performance of soft tissue } \\
\text { oedema to diagnose PsA vs } \\
\text { RA: } \\
\text { Se }(95 \% \mathrm{CI}) 0.42(0.23,0.63) \\
\text { Sp }(95 \% \mathrm{CI}) 0.97(0.84,0.99) \\
\text { LR+ } 14.38(1.98,104.44) \\
\text { LR- } 0.59(0.43,0.83) \\
\text { PPV } 0.91(0.60,0.98) \\
\text { NPV } 0.68(0.61,0.75)\end{array}$ \\
\hline $\begin{array}{l}\text { Tinazzi } \\
2018 \\
{[9]}\end{array}$ & $\begin{array}{l}37 \mathrm{PsA} \\
47 \mathrm{PsA} \\
10 \mathrm{HC}\end{array}$ & $\begin{array}{l}\text { US of the flexor } \\
\text { compartment } \\
\text { of the hands } \\
\text { (fingers 2-4) } \\
\text { by GS and PD. } \\
16-18 \mathrm{MHz} \\
\text { transducer }\end{array}$ & $\begin{array}{l}\text { Clinical } \\
\text { diagnosis }\end{array}$ & $\begin{array}{l}\text { "Peritendinous oedema was de- } \\
\text { fined as a diffuse hypo/isoechoic } \\
\text { thickening of the peritendinous } \\
\text { soft tissues around flexor tendon } \\
\text { with vascular signal at PD } \\
\text { examination". } \\
\text { The outcome was the diagnosis } \\
\text { of PsA. }\end{array}$ & $\begin{array}{l}\text { Performance of soft tissue } \\
\text { oedema (GS) to diagnose } \\
\text { PsA vs RA: } \\
\text { Se }(95 \% \mathrm{CI}) 0.56(0.42,0.75) \\
\text { Sp }(95 \% \mathrm{CI}) 1(0.92,1) \\
\text { LR- }(95 \% \mathrm{CI}) 0.41(0.27,0.6) \\
\text { PPV }(95 \% \mathrm{CI}) 1 \\
\text { NPV }(95 \% \text { CI })(0.67,0.81)\end{array}$ \\
\hline $\begin{array}{l}\text { Zabotti } \\
2018 \\
{[7]}\end{array}$ & $\begin{array}{l}25 \text { seropositive } \\
\text { early RA } \\
23 \text { seronegative } \\
\text { early RA } \\
25 \text { early PsA }\end{array}$ & $\begin{array}{l}\text { US of the volar } \\
\text { aspect } \\
\text { of the hands } \\
16-18 \mathrm{MHz} \\
\text { transducer }\end{array}$ & $\begin{array}{l}\text { Clinical } \\
\text { diagnosis }\end{array}$ & $\begin{array}{l}\text { Soft tissue oedema around the } \\
\text { flexor tendon defined as "dif- } \\
\text { fuse enlargement of soft tissue } \\
\text { round the flexor tendon, with an } \\
\text { increased power Doppler signal, } \\
\text { from finger pad to MCP joint, } \\
\text { and it was evaluated by volar } \\
\text { scan". } \\
\text { The outcome was the diagnosis } \\
\text { of PsA. }\end{array}$ & $\begin{array}{l}\text { Performance of soft tissue } \\
\text { oedema to diagnose PsA: } \\
\text { Se }(95 \% \text { CI } 0.4(0.21,0.61) \\
\text { Sp }(95 \% \text { CI } 0.9(0.77,0.97) \\
\text { LR+ } 4.2(1.47,11.98) \\
\text { LR- } 0.66(0.47,0.93) \\
\text { PPV } 0.71(0.46,0.087) \\
\text { NPV } 0.71(0.64,0.77)\end{array}$ \\
\hline
\end{tabular}


rate). At the first round, the Delphi survey consisted of eleven statements and modifications were done step by step as the procedure went on, as reported in tables II, III and IV. At the first round, a consensus was achieved on the site to evaluate finger STOe, with $91 \%$ of participants proposing a volar evaluation rather than only a dorsal $(0 \%$ of agreement) or dorsal plus volar (50\% of agreement). Participants agreed to use a contralateral finger as a comparison to assess the presence of abnormal STOe (91\% of agreement; table II). In cases of contralateral swollen or painful fingers the nearest normal finger should be used as a comparison. At the second round participants agreed to define STOe as "abnormal hypoechoic/anechoic areas, diffused or localized within the subcutaneous tissue between the epidermidis and the tendon-related anatomic structures (i.e. flexor tendon sheath, peritenonium, tendon pulleys), with local thickening, with or without local abnormal power Doppler signal, visualised in two perpendicular planes and not evident on the contralateral side" ( $76 \%$ of agreement; table III). At round 3, participants agreed to propose 4-points (0-3) semiquantitative scores for both grey scale lesions and power Doppler (PD) findings in the presence of soft tissue oedema $(0=$ no abnormalities; $1=$ mild; $2=$ moderate; $3=$ severe lesions, as reported in table II; $76 \%$ of agreement; table IV). Both those scores need the comparison with the contralateral normal finger (91\% of agreement). Representative images of the agreed lesions and scoring systems both for grey scale and PD are shown in figures 2 and 3. Moreover, all the participants of Delphi process agreed to examine STOe with a probe of at least $18 \mathrm{MHz}$ and to optimize the gain setting in order to improve soft tissue visualization. For PD signal, we agreed to use a $10 \mathrm{MHz}$ frequency at least and up to 0.8 PRF. Gain should be set in order to avoid artifacts and optimize sensitivity.

\section{Discussion}

Dactylitis occurs commonly in PsA and since it is a marker of disease severity and it is associated with destructive bone lesions, its presence should suggest to the physician to start specific treatments [2].

Animal models of PsA-like disease underlined the crucial role of pro-inflammatory cytokines in the pathogenesis of dactylitis, with an initial aberrant innate immune response to biomechanical stress or injury and subsequent adaptive immune mechanisms that could amplify inflammatory response, then causing the diffuse swelling of the digit [13]. Inflammation involving many anatomical structures is relevant in dactylitis but the pivotal role of soft tissue oedema in this pathological condition was also confirmed in SpA animal models (e.g.

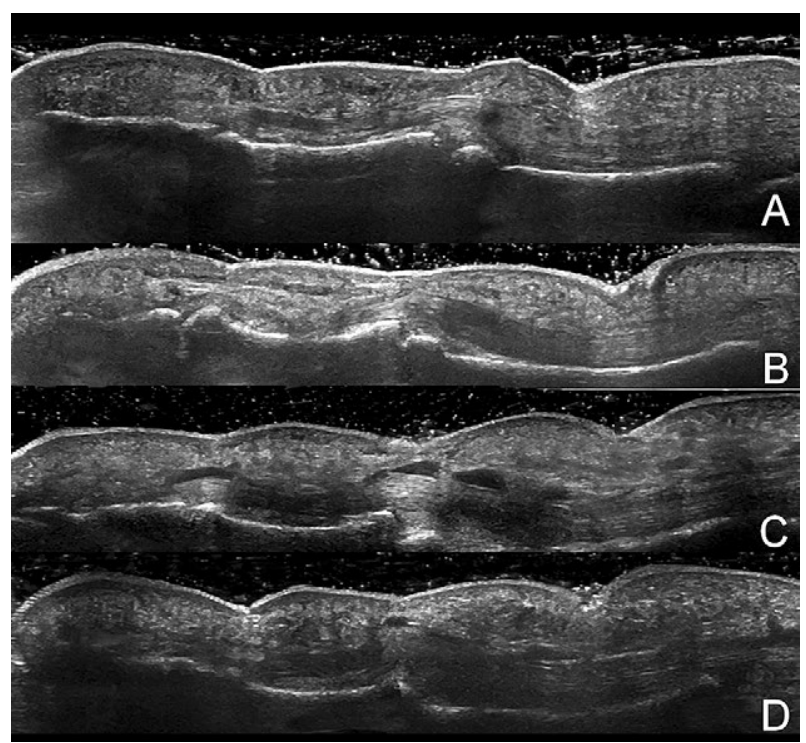

Fig 2. Explicative image of grading of soft tissue finger oedema in grayscale. From top (A) to bottom (D) the grade changes from 0 up to 3 . In (A) no hypoechoic spots appear with the exception of the lumen of normal vessels. In (B) an evidence of mild hypoechoic areas is present, especially at proximal phalanx. This is more evident in (C) both for proximal and intermediate phalanx and soft tissue involvement is very well observed in (D). Note that tenosynovitis is not considered in the definition so the presentation of tenosynovitis does not affect the severity of grade as it happens in (C).

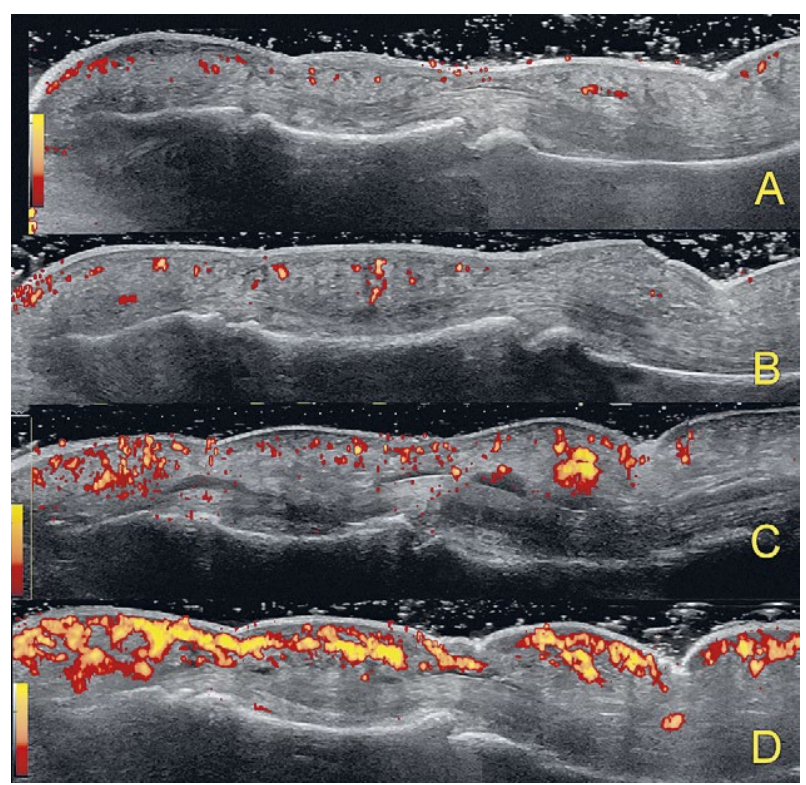

Fig 3. Explicative image of the power Doppler grading of soft tissue finger oedema. From top (A) to bottom (D) the grade changes from 0 up to 3 . In (A) only signals from normal vessels can be visualized. In (B) an evidence of mild increase of signal is noted if compared with contralateral. This becomes more and more evident with an increasing of the signal that reaches the highest grade in D. 
DBA/1 model, IL23 overexpression model) $[14,15]$. The clinical identification of dactylitis is useful in differential diagnosis of early arthritis $[7,10]$ and US detection of STOe, even without clinically evident dactylitis, could be relevant for differential diagnosis purposes, particularly in early arthritis [7-9]. Currently, a sonographic definition and score of STOe in patients with arthritis is still lacking. In this paper we propose both a new US definition and a scoring method for finger STOe, giving also indications on the optimal US scanning technique to use

Table II. Statements on definitions of an ultrasound (US) elementary lesion of soft tissue finger oedema in normal and pathologic conditions agreed upon via a Delphi survey during the first round (13 participants)

\begin{tabular}{lll}
\hline Domain $\quad$ Definition & $\begin{array}{l}\text { Agreement } \\
(\%)\end{array}$ & $(\%)$ \\
\hline
\end{tabular}

US evaluation of finger soft tissue oedema

Site of assessment An optimal US assessment of finger oedema includes only volar scan 91

An optimal US assessment of finger oedema includes only dorsal scan 0

An optimal US assessment of finger oedema includes both volar and dorsal scan $\quad 50$

Abnormal soft tissue oedema (US definition)

Abnormal hypoechoic/anechoic areas, diffuse or localized within the subcutaneous tissue present between the epidermidis and the tendon-related anatomic structures (flexor tendons sheath, peritenonium, tendon pulleys), with or without local pathological Doppler signal, visualised in two perpendicular planes

Abnormal hypoechoic/anechoic areas, diffuse or localized within the subcutaneous tissue present between the epidermidis and the tendon-related anatomic structures (flexor tendons sheath, peritenonium, tendon pulleys), with local thickening of the subcutaneous tissues, with or without local pathological Doppler signal, visualised in two perpendicular planes

\section{Comparison of US findings with the contralateral normal side}

An optimal US assessment of finger oedema includes the comparison with the contralateral normal side (excluding tender/swollen finger)

In case of tender/swollen contralateral finger the nearest normal finger should be considered for comparison

\section{Comparison of US findings with the contralateral normal side}

An optimal US assessment of finger oedema includes the comparison with the contralateral normal side (excluding tender/swollen finger)

In case of tender/swollen contralateral finger or the nearest normal finger should be considered for comparison

\section{Quantification of soft tissue oedema}

Semiquantitative A semiquantitative score is useful for diagnostic purposes

A dichotomic score is useful only for follow up

\section{Gray-scale US scoring systems for assessing finger oedema}

Grade $0 \quad$ No finger oedema

Grade 1

Presence of finger oedema only at the level of one phalanx

Grade 2

Presence of finger oedema at the level of two phalanxes

Grade 3

Presence of finger oedema at the level of three phalanxes

\section{Doppler scoring systems to use in the presence of finger oedema}

Grade $0 \quad$ No Doppler signal in the subcutaneous tissues in the presence of finger oedema

Grade 1

1 or 2 Doppler signals in the subcutaneous tissues in the presence of finger oedema

Grade 2

$>2$ isolated or confluent Doppler signals in the subcutaneous tissues in the presence of finger oedema but without extensive Doppler signal 
for this peculiar lesion. The process that we conducted included a SLR and, on its basis, the development of a Delphi survey. The participants in this study were all expert ultrasonographers with a specific interest in PsA research using US and could then significantly contribute to the work. After three Delphi rounds, we obtained: I) technical indications on how to optimize the assessment of STOe; II) an agreed definition of STOe in PsA dactylitis; and III) a B-mode and PD score to quantify the severity of STOe. The experts agreed to choose the unaffected (defined as finger without swelling and pain at clinical examination) controlateral side as comparator to detect STOe. Some of the experts gave more importance to the quantification of STOe in the whole finger with the use of a the semiquantitative system while others considered it more relevant to look at the topographic extension of STOe. The Delphi process led to an agreement on this topic, that consisted of the application of a semiquantitative scoring method of STOe at the level of the involved finger, which was based on the presence of alterations at the level of the three segments of the finger (proximal, intermediate and distal phalanx area),in comparison with the contralateral unaffected finger.

By proposing a sonographic definition of pathology and a scoring of local lesions present in PsA dactylitis, this work represents a first step of a complex process which will thereafter be focused on evaluating the reliability of US in the assessment of dactylitis. Those developments will be conducted by a web-based test and subsequently a patient-based exercise.

Table III. Statements on definitions of the ultrasound (US) elementary lesion of soft tissue finger oedema in normal and pathologic conditions agreed upon via a Delphi survey during the second round (13 participants).

\begin{tabular}{lll}
\hline Domain & Definition & $\begin{array}{l}\text { Agreement } \\
(\%)\end{array}$ \\
\hline
\end{tabular}

US evaluation of finger soft tissue oedema

Abnormal soft Abnormal hypoechoic/anechoic areas, diffuse or localized within the subcutaneous tissue tissue oedema present between the epidermidis and the tendon-related anatomic structures (i.e. flexor tendons (US definition) sheath, peritenonium, tendon pulleys), with local thickening, with or without local abnormal Doppler signal, visualised in two perpendicular planes and not evident on the contralateral side

Abnormal inhomogeneous hypoechoic/anechoic areas, diffuse or localized within the subcutaneous tissue present between the epidermidis and the tendon-related anatomic structures (i.e. flexor tendon sheath, peritenonium, tendon pulleys), with or without local abnormal Doppler signal, visualised in two perpendicular planes and not evident on the contralateral side

\section{Quantification of soft tissue oedema}

Semiquantitative A semiquantitative score is useful for both diagnostic purposes and follow up

versus

dichotomic score

A semiquantitative score should be used for assessing grey-scale abnormalities and PD pathological flow where finger oedema is present

\section{Gray-scale US scoring systems for assessing finger oedema}

Grade 0

Grade 1

presence of finger oedema represented by 1 or 2 anechoic/inhomogeneous areas in the subcutaneus tissues, not evident in the contralateral side

Grade 2 presence of finger oedema represented by more than 2 anechoic/inhomogeneous areas in the subcutaneus tissues, not evident in the contralateral side

Grade 3 presence of extensive anechoic/inhomogeneous areas in the subcutaneus tissues, not evident in the contralateral side

\section{Doppler scoring systems to use in the presence of finger oedema}

Grade $0 \quad$ Same number of Doppler signals as the contralateral side, localised in the subcutaneous soft tissues, in the presence of finger oedema

Grade $1 \quad$ Mild increased number (1 or 2) of Doppler signals compared to the contralateral side, localised in the subcutaneous soft tissues, in the presence of finger oedema

Grade 2

Moderate increase (more than 2) of Doppler signals compared to the contralateral side, localised in the subcutaneous soft tissues, in the presence of finger oedema

Grade 3

Extensive Doppler signal compared to the contralateral side, localised in the subcutaneous soft tissues, in the presence of finger oedema 
Table IV. Statements on definitions of the ultrasound (US) elementary lesion of soft tissue finger oedema in normal and pathologic conditions agreed upon via a Delphi survey during the third round (13 participants)

\begin{tabular}{|c|c|c|}
\hline Domain & Definition & $\begin{array}{l}\text { Agreement } \\
(\%)\end{array}$ \\
\hline \multicolumn{2}{|c|}{ Quantification of tissue edema: Gray-scale US scoring systems for assessing finger oedema } & 76 \\
\hline Grade 0 & No finger oedema & \\
\hline Grade 1 & $\begin{array}{l}\text { Presence of mild abnormal (when compared with the contralateral finger) anechoic/hypoechoic } \\
\text { areas within the subcutaneous tissues present between the epidermidis and the tendon-related } \\
\text { anatomic structures localized only in one phalanx }\end{array}$ & \\
\hline Grade 2 & $\begin{array}{l}\text { Presence EITHER of moderately abnormal (when compared with the contralateral finger) } \\
\text { anechoic/hypoechoic areas within the subcutaneous tissues present between the epidermidis } \\
\text { and the tendon-related anatomic structures localized only in one phalanx OR presence of mild } \\
\text { abnormal areas but present in two/three phalanxes }\end{array}$ & \\
\hline Grade 3 & $\begin{array}{l}\text { Presence EITHER of severely abnormal (when compared with the contralateral finger) anechoic/ } \\
\text { hypoechoic areas within the subcutaneous tissues present between the epidermidis and the } \\
\text { tendon-related anatomic structures, localized at least in one phalanx OR moderately abnormal } \\
\text { areas in two/three phalanxes }\end{array}$ & \\
\hline \multicolumn{2}{|c|}{ Quantification of tissue edema: Doppler scoring US scoring systems for assessing finger oedema } & 76 \\
\hline Grade 0 & $\begin{array}{l}\text { Same number of Doppler signals as the contralateral side, localised in the subcutaneous soft } \\
\text { tissues, in the presence of finger oedema }\end{array}$ & \\
\hline Grade 1 & $\begin{array}{l}\text { Mild increased number of Doppler signals compared to the contralateral side, localised in the } \\
\text { subcutaneous soft tissues in only one phalanx, in the presence of finger oedema }\end{array}$ & \\
\hline Grade 2 & $\begin{array}{l}\text { Moderate increased number of Doppler signals compared to the contralateral side, localised in } \\
\text { the subcutaneous soft tissues in only one phalanx OR mild increased number of Doppler signals } \\
\text { in two/three phalanxes, in the presence of finger oedema }\end{array}$ & \\
\hline Grade 3 & $\begin{array}{l}\text { Severe increase of Doppler signals compared to the contralateral side, localised in the subcuta- } \\
\text { neous soft tissues in at least one phalanx, or moderate increase in two/three phalanxes }\end{array}$ & \\
\hline
\end{tabular}

\section{References}

1. Zabotti A, Idolazzi L, Batticciotto A, et al. Enthesitis of the hands in psoriatic arthritis: an ultrasonographic perspective. Med Ultrason 2017;19:438-443.

2. Brockbank JE, Stein M, Schentag CT, Gladman DD. Dactylitis in psoriatic arthritis: a marker for disease severity? Ann Rheum Dis 2005;64:188-190.

3. Bruyn GA, Hanova P, Iagnocco A, et al. Ultrasound definition of tendon damage in patients with rheumatoid arthritis. Results of a OMERACT consensus-based ultrasound score focussing on the diagnostic reliability. Ann Rheum Dis 2014;73:1929-1934.

4. Terslev L, Naredo E, Aegerter P, et al. Scoring ultrasound synovitis in rheumatoid arthritis: a EULAR-OMERACT ultrasound taskforce-Part 2: reliability and application to multiple joints of a standardised consensus-based scoring system. RMD Open 2017;3:e000427.

5. Naredo E, D’Agostino MA, Wakefield RJ, et al. Reliability of a consensus-based ultrasound score for tenosynovitis in rheumatoid arthritis. Ann Rheum Dis 2013;72:13281334.

6. Fournié B, Margarit-Coll N, Champetier de Ribes TL, et al. Extrasynovial ultrasound abnormalities in the psoriatic finger. Prospective comparative power-doppler study versus rheumatoid arthritis. Joint Bone Spine 2006;73:527531.
7. Zabotti A, Errichetti E, Zuliani F, et al. Early Psoriatic Arthritis Versus Early Seronegative Rheumatoid Arthritis: Role of Dermoscopy Combined with Ultrasonography for Differential Diagnosis. J Rheumatol 2018;45:648-654.

8. Zabotti A, Salvin S, Quartuccio L, De Vita S. Differentiation between early rheumatoid and early psoriatic arthritis by the ultrasonographic study of the synovio-entheseal complex of the small joints of the hands. Clin Exp Rheumatol 2016;34:459-465.

9. Tinazzi I, McGonagle D, Zabotti A, et al. Comprehensive evaluation of finger flexor tendon entheseal soft tissue and bone changes by ultrasound can differentiate psoriatic arthritis and rheumatoid arthritis. Clin Exp Rheumatol 2018;36:785-790.

10. Zabotti A, Bandinelli F, Batticciotto A, et al. Musculoskeletal ultrasonography for psoriatic arthritis and psoriasis patients: a systematic literature review. Rheumatology (Oxford) $2017 ; 56: 1518-1532$.

11. Fournié B, Crognier L, Arnaud C, et al. Proposed classification criteria of psoriatic arthritis. A preliminary study in 260 patients. Rev Rhum Engl Ed 1999;66:446-456.

12. Lin Z, Wang Y, Mei Y, Zhao Y, Zhang Z. High-Frequency Ultrasound in the Evaluation of Psoriatic Arthritis: A Clinical Study. Am J Med Sci 2015;350:42-46.

13. McGonagle D, Tan AL, Watad A, Helliwell P. Pathophysiology, assessment and treatment of psoriatic dactylitis. Nat Rev Rheumatol 2019;15:113-122. 
Med Ultrason 2019; 21(4): 414-421 421

14. Lories RJ, Matthys P, de Vlam K, Derese I, Luyten FP. Ankylosing enthesitis, dactylitis, and onychoperiostitis in male DBA/1 mice: a model of psoriatic arthritis. Ann Rheum Dis 2004;63:595-598.
15. Sherlock JP, Joyce-Shaikh B, Turner SP, et al. IL-23 induces spondyloarthropathy by acting on ROR- $\gamma \mathrm{t}+\mathrm{CD} 3+\mathrm{CD} 4-$ CD8- entheseal resident T cells. Nat Med 2012;18:10691076. 